\title{
MAY-JUNE 1984
}

TWENTY-FOURTH YEAR - No. 240
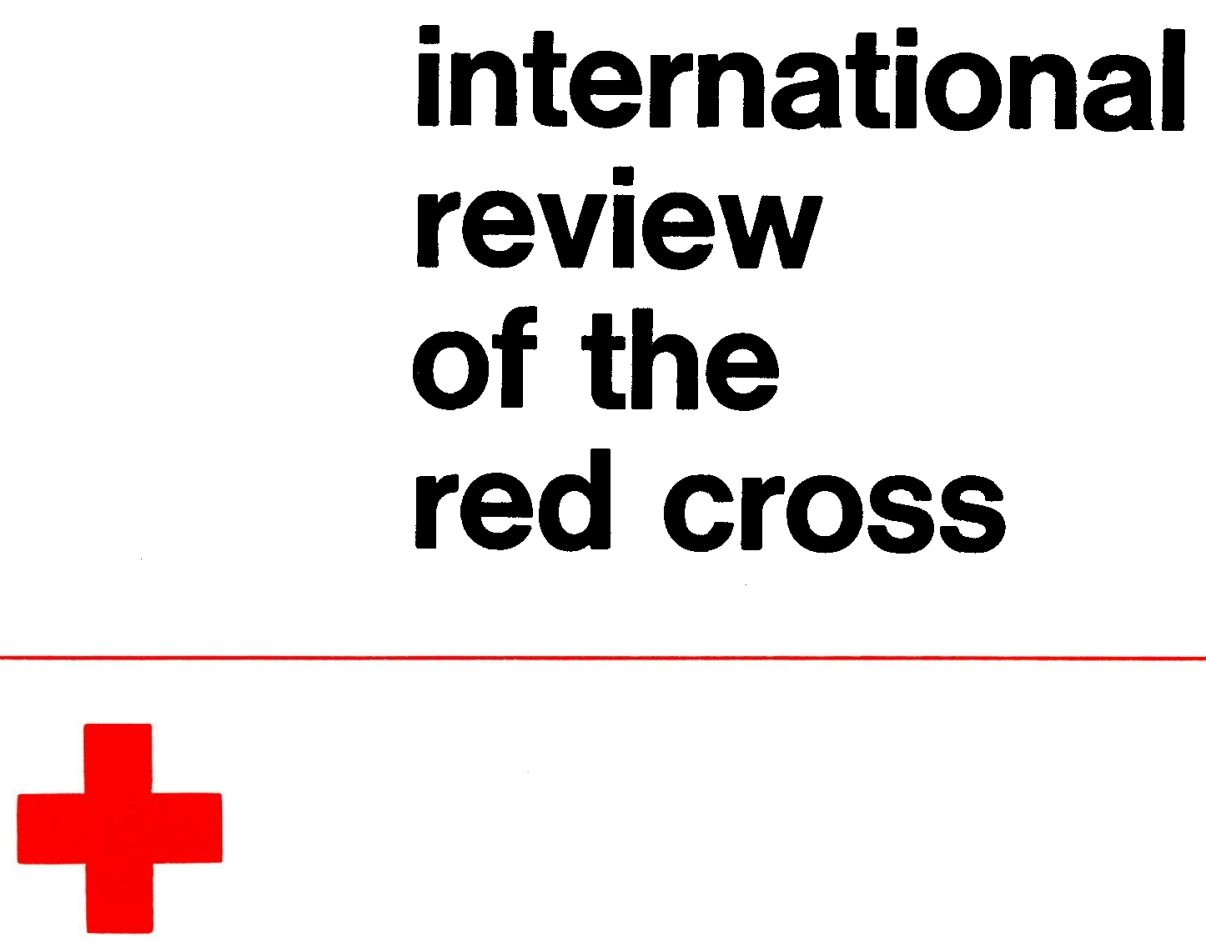

INTER ARMA CARITAS

GENEVA

INTERNATIONAL COMMITTEE OF THE RED CROSS FOUNDED IN 1863 


\title{
INTERNATIONAL COMMITTEE OF THE RED CROSS
}

Mr. ALEXANDRE HAY, Lawyer, former Director-General of the Swiss National Bank, President (member since 1975)

Mr. MAURICE AUBERT, Doctor of Laws, Vice-President (1979)

Mr. VICTOR H. UMBRICHT, Doctor of Laws, Managing Director, Vice-President (1970)

Mr. JEAN PICTET, Doctor of Laws, former Vice-President of the ICRC (1967)

Mrs. DENISE BINDSCHEDLER-ROBERT, Doctor of Laws, Professor at the Graduate Institute of International Studies, Geneva, Judge at the European Court of Human Rights (1967)

Mr. JACQUES F. DE ROUGEMONT, Doctor of Medicine (1967)

Mr. GILBERT ETIENNE, Professor at the Graduate Institute of International Studies and at the Institut universitaire d'études du développement, Geneva (1973)

Mr. ULRICH MIDDENDORP, Doctor of Medicine, head of surgical department of the Cantonal Hospital, Winterthur (1973)

Mrs. MARION BOVÉE-ROTHENBACH, Doctor of Sociology (1973)

Mr. HENRY HUGUENIN, Banker (1974)

Mr. RICHARD PESTALOZZI, Doctor of Laws, former Vice-President of the ICRC (1977)

Mr. ATHOS GALLINO, Doctor of Medicine, Mayor of Bellinzona (1977)

Mr. ROBERT KOHLER, Master of Economics (1977)

Mr. RUDOLF JÄCKLI, Doctor of Sciences (1979)

Miss ANDREEE WEITZEL, former head of the women's auxiliary service at the Federal Military Department, vice-president of the Swiss national Commission for Unesco (1979)

Mr. OLIVIER LONG, Doctor of Laws and Doctor of Political Science, Ambassador, former Director General of GATT (1980)

Mr. DIETRICH SCHINDLER, Doctor of Laws, Professor at the University of Zürich (1961-1973; 1980)

Mr. HANS HAUG, Doctor of Laws, Professor at the St-Gall School of Advanced Economic and Social Studies, former President of the Swiss Red Cross (1983)

Mr. PETER ARBENZ, Bachelor of Political Science, member of the Central Committee of Helvetas, municipal councillor of Winterthur (1983)

Mr. PIERRE KELLER, Doctor of Philosophy in International Relations (Yale), banker (1984)

Mr. RAYMOND R. PROBST, Doctor of Laws, former Swiss Ambassador, former Secretary of State at the Federal Department of Foreign Affairs, Berne (1984)

\section{EXECUTIVE COUNCIL}

\author{
Mr. ALEXANDRE HAY, President \\ Mr. MAURICE AUBERT \\ Mr. RICHARD PESTALOZZI \\ Mr. ATHOS GALLINO \\ Mr. RUDOLF JÄCKLI \\ Miss ANDRÉE WEITZEL \\ Mr. OLIVIER LONG
}

The International Committee of the Red Cross (ICRC), together with the League of the Red Cross and Red Crescent Societies and the 132 recognized National Red Cross and Red Crescent Societies, is one of the three components of the International Red Cross.

An independent humanitarian institution, the ICRC is the founding body of the Red Cross. As a neutral intermediary in case of armed conflicts or disturbances, it endeavours on its own initiative or on the basis of the Geneva Conventions to protect and assist the victims of international and civil wars and of internal troubles and tensions, thereby contributing to peace in the world. 


\title{
CONTENTS
}

\section{INTERNATIONAL REVIEW OF THE RED CROSS}

\author{
ISSN 0020-8604
}

May - June 1984 - No. 240

Hans Haug : Can the Red Cross contribute to safeguarding peace? . . . . . . . .

Denise Plattner : Protection of Children in International Humanitarian Law . . . . . . . 140

INTERNATIONAL COMMITTEE OF THE RED CROSS

IN THE RED CROSS WORLD

BOOKS AND REVIEWS mational Humanitarian Law $\cdot \cdot \cdot \cdot \cdot \cdot 10$

The ICRC President re-elected . . . . . . . . 153

President of Costa Rica visits ICRC . . . . . 153

The President of the ICRC visits the League of Arab States . . . . . . . . . 153

ICRC President in Saudi Arabia and Libya . . 154

Accession of the Republic of Cape Verde to the

Geneva Conventions . . . . . . . 155

Ratification of the Protocols by the Togolese

Republic . . . . . . . . 155

External activities:

Africa - Latin America - Asia - Middle East 156

Fifteenth Conference of the Arab Red Cross and Red Crescent Societies . . . . . . . 173

Sixty-third distribution of income of the Empress Shôken Fund . . . . . . . 174

Voluntary Service by the Red Cross in presentday Society (Jacques Meurant) . . . . . 179

International Red Cross Handbook . . . . . 181

Development and Principles of International Humanitarian Law (Jean Pictet) . . . . 182

Studies and Essays in honour of Jean Pictet . . 183 
International Review of the Red Cross has been published, in French, under various titles, by the International Committee of the Red Cross (ICRC) since 1869. Its first complete edition in English was issued in 1961.

- As the official organ of the ICRC and the International Red Cross,

- specializing in international humanitarian law and ICRC doctrine,

- recording the international activities of the Red Cross, mainly for reference purpose, as a chronicle of events,

International Review of the Red Cross provides a constant flow of information and maintains the necessary link between the members of the International Red Cross.

International Review of the Red Cross appears once every two months in three languages:

in English: INTERnational Review of THE Red Cross (from 1961)

in French: Revue INTERnationale de la Croix-Rouge

in Spanish: Revista INTERNAcional de la CRUz Roja (from 1976)

It also publishes, in German, a short edition, Extracts, of various articles which appear in the main editions.

\section{EDITOR: Michel Testuz}

ADDREss: International Review of the Red Cross

17, Avenue de la Paix

CH - 1211 Geneva, Switzerland

SuBSCRIPTIONS: one year, Sw. frs. 30.-; single copy Sw. frs. 5.-

Extracts in German: one year, Sw. frs. 10.-; single copy Sw. frs. 2.-

Postal Cheque Account: No. 12 - 1767 Geneva

Bank account No. 129.986 Swiss Bank Corporation, Geneva

The International Committee of the Red Cross assumes responsibility only for material over its own signature. 